\title{
Revalidation of Santinezia albilineata Roewer, 1932 (Arachnida: Opiliones: Cranaidae)
}

\author{
Manzanilla Osvaldo Villarreal ${ }^{1} \&$ Carlos J. Rodríguez ${ }^{2}$ \\ 1,2 Museo del Instituto de Zoología Agrícola, Facultad de Agronomía, Universidad Central de Venezuela, Apartado 4579, Maracay \\ 2101, Venezuela \\ Email: ${ }^{1}$ osvaldovillarreal@gmail.com (corresponding author), ${ }^{2}$ aldaroncr@gmail.com
}

\begin{abstract}
Santinezia albilineata Roewer, 1923 is revalidated from the synonymy of Santinezia curvipes (Roewer, 1916). Both species, which inhabit the central northern costal mountain range in Venezuela, are illustrated and compared. Santinezia albilineata can be differentiated easily from $S$. curvipes, by the following characters of the males: development and direction of the ventral process of the coxa IV, direction of the retrolateral distal tubercle of the trochanter IV, perpendicular with blunt tip in S. albilineata and sharp and posteriorly projected in S. curvipes; retrolateral proximal tubercle of the femur IV absent, this is present in S. curvipes. The genital characters in S. albilineata are: ventral plate with five lateral setae, the three proximal aligned and larger. Distal setae distal straight. With two small mesodorsal setae. S. curvipes ventral plate with five non-aligned lateral setae, the basal largest and located at the height of the lateral expansion, the four remaining grouped medially. Absence of mesodorsal setae.
\end{abstract}

Keywords: Gonyleptoidea, Laniatores, taxonomy, Venezuela.

The knowledge of taxonomy of the genera in Cranaidae is unsatisfactory and the generic boundaries are not clearly established. An attempt to define the status of subfamilies was recently made (Orrico \& Kury

Date of publication (online): 26 November 2011

Date of publication (print): 26 November 2011

ISSN 0974-7907 (online) | 0974-7893 (print)

Editor: Adriano B. Kury

Manuscript details:

Ms \# 02514

Received 21 July 2010

Final received 08 April 2011

Finally accepted 02 November 2011

Citation: Villarreal, M.O. \& C.J. Rodríguez (2011). Revalidation of Santinezia albilineata Roewer, 1932 (Arachnida: Opiliones: Cranaidae). Journal of Threatened Taxa 3(11): 2202-2206.

Copyright: ( ) Manzanilla Osvaldo Villarreal \& Carlos J. Rodríguez 2011. Creative Commons Attribution 3.0 Unported License. JoTT allows unrestricted use of this article in any medium for non-profit purposes reproduction and distribution by providing adequate credit to the authors and the source of publication.

Acknowledgements: Adriano Kury and Ricardo Pinto-da-Rocha selflessly provided important information and comments. Rubén Candia (MB-UCV, Venezuela) provided information on the types of Cranaostygnus marcuzzi.

OPEN ACGESS | FREE DOWNLOAD
2009), however a systematic revision is yet needed. The only cranaine genus studied under phylogenetic treatment is Santinezia Roewer, 1923, which has almost 30 species described from Panama to Brazil, with an Andean-Amazonic distribution, and only one species from Central America (Kury 2003; Pinto-daRocha \& Kury 2003; Townsend \& Milne 2010).

In a taxonomic review of Santinezia from Venezuela (González-Sponga 2003), 11 new species and two new subspecies were described and a new combination was proposed; a few months later, a taxonomic and systematic review of the genus was published (Pintoda-Rocha \& Kury 2003), which included only species prior to the aforementioned paper, being composed of 17 species assembled in three groups: curvipes, festae and gigantea, distributed in northern South America.

Both articles reached similar conclusions in several taxonomic points, as in the establishment of the synonymy between $S$. francourbanii Avram, 1987 and S. curvipes Roewer, 1916, however, there are some points of disagreement on the taxonomic status of three populations of the genus inhabiting the central track of Cordillera de La Costa, in Venezuela, specifically: Henri Pittier National Park, a locality near San Casimiro (both in the Aragua State) and El Avila National Park (in the Capital District and Miranda State). While González-Sponga (2003), accepts these three populations as an equal number of species $(S$. curvipes - Distrito Capital and Miranda; S. marcuzzii - north of Aragua State and S. albilineata - south of Aragua State), Pinto-da-Rocha \& Kury (2003) recognize only one species: $S$. curvipes.

In the present note the external morphology and the genital structure of the males of three localities were studied, to resolve the taxonomic status of populations referred as Santinezia curvipes (Roewer, 1916) or its current synonym: S. albilineata Roewer, 1923, and the revalidation of the last species is proposed. 
Repositories are Museo de Historia Natural La Salle, Caracas (MHNLS) and Museo del Instituto de Zoología Agrícola, UCV - Maracay (MIZA).

\section{Taxonomy}

\section{Cranaidae Roewer, 1913}

Santinezia Roewer, 1923

Inezia Roewer 1913: 392. Preoccupied by Inezia Cherrie, 1909.

Santinezia Roewer 1923: 552; Pinto-da-Rocha \& Kury 2003: 181; Kury 2003: 97; González-Sponga 2003: 3 .

Nieblia Roewer 1925: 27. (Synonymy established by Pinto-da-Rocha \& Kury 2003: 181).

Ikossimus Roewer 1931: 334. (Synonymy established by González-Sponga 2003: 3).

Cranaostygnus Caporiacco, 1951. (Synonymy established by González-Sponga, 2003: 3).

\section{Santinezia curvipes (Roewer, 1916) Images 1-5; Figs. 1-6}

Inezia curvipes Roewer, 1916: 8.

Santinezia curvipes Roewer, 1932: 553; Roewer, 1932: 290; Soares \& Soares, 1948: 617; Moritz, 1971: 195; Avram, 1987: 84; González-Sponga, 2003: 42; Pinto-da-Rocha \& Kury, 2003: 26.

Cranaostygnus marcuzzi Caporiacco, 1951: 26. (Synonymy established by Pinto-da-Rocha \& Kury, 2003).

Santinezia marcuzzii (misspelling): GonzálezSponga, 2003: 3 and 45.

Goniosoma pavani Muñoz-Cuevas, 1972: 28. (Synonymy established by González-Sponga, 2003).

Santinezia benedictoi Soares \& Avram, 1981: 95. (Synonymy established by González-Sponga, 2003).

Santinezia francourbanii Avram, 1987: 83; Rambla \& Juberthie, 1994: 221. (Synonymy established by González-Sponga, 2003).

Santinezia orghidani Avram, 1987: 85. (Synonymy established by González-Sponga, 2003).

Santinezia orhidani (misspelling): GonzálezSponga, 2003: 45.

Material examined: 21.viii.1998, 1 male, 1 female, $1675 \mathrm{~m}$, Parque Nacional El Ávila, Los Mecedores, Distrito Capital, Venezuela (MHNLS IV-252) (H. Escalona); 30.vi.2009, 5 males, 7 females $1500 \mathrm{~m}$, Parque Nacional El Ávila, Los Venados (MIZA 2181)
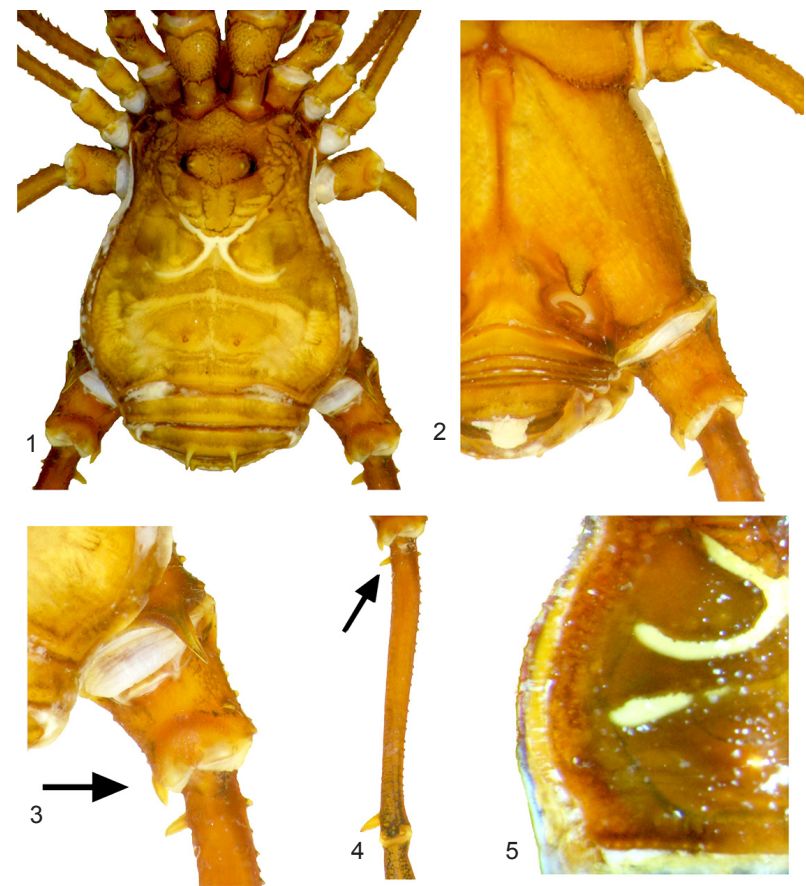

Images 1-5. Santinezia curvipes (male from Rancho Grande, Aragua): 1 - Habitus in dorsal view; 2 - Coxa IV, stigmatic area and free sternites in ventral view; 3 - Right trochanter IV in dorsal view; the arrow pointing the retrolateral tubercle on the trochanter; 4 - Right femur IV, in dorsal view; the arrow pointing the proximal and retrolateral tubercle on the femur; 5 - Female from El Ávila, Miranda. Left posterolateral zone of dorsal scute, in dorsal view.

(O. Villarreal M.; L. Ovalles); 05.iv.2009, 5 males, 1 female, 1200-1300 m, Parque Nacional Henri Pittier, camino Rancho Grande-Cumbre, Aragua (MIZA 1717) (O. Villarreal M.; H. Escalona); 09.x.2008, 1 male, Parque Nacional Henri Pittier camino Pico PeriquitoPortachuelo, Aragua (MIZA 1353) (H. Sánchez; O.Villarreal M.; J. Valera; I. Salvi).

Emended diagnosis: Carapace reticulated dark brown on yellowish-brown background; abdominal scute reddish-brown with mesotergal areas slightly darker (Image 1). Ventral tubercles of the coxa IV short (two times larger than wide), projected posteriorly, forming an acute angle with the rear margin of the coxa (Image 2); retrolateral distal tubercle of the trochanter IV sharp and posteriorly projected (Image 3 ); presence of a retrolateral proximal tubercle in the femur IV (Images 3-4). Penis: Ventral plate with five non-aligned lateral setae, basal largest and located at the height of lateral expansion, the four remaining grouped medially. Absence of mesodorsal setae; distal setae of the ventral plate curved. Distal cleft of the ventral plate shallow. Ratio length/width of the plate 

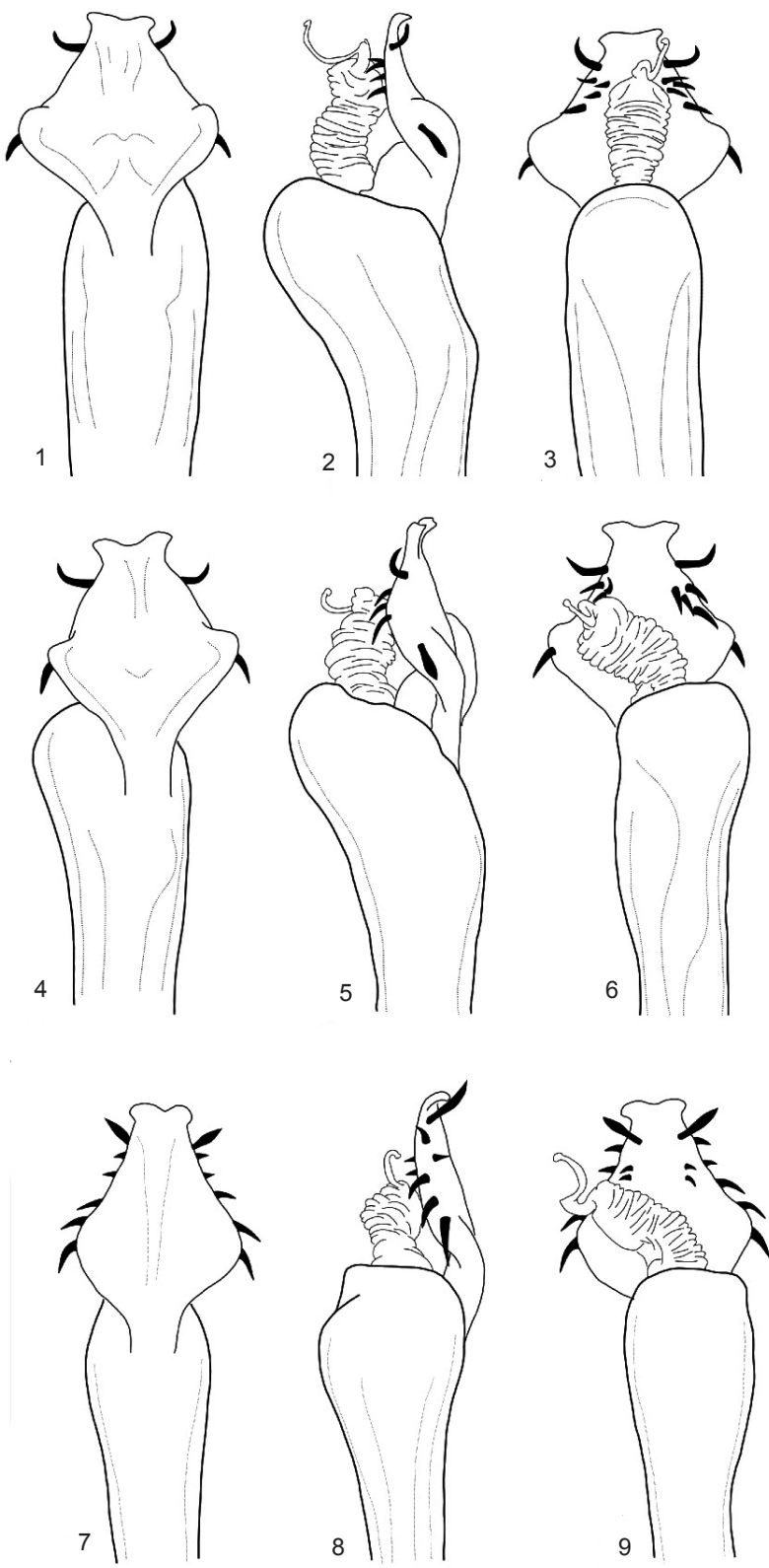

Figures 1-9. Santinezia spp., distal portion of the penis: ventral, lateral and dorsal views. 1-3 - Santinezia curvipes (P.N. Henri Pittier, Aragua state); 4-6 - Santinezia curvipes (P.N. Avila, Distrito Capital); 7-9 - Santinezia albilineata (Tiara, Aragua state).

ventral 1.13-1.25. Apical portion of the penis trunk dorsally projected (Figs. 1-6). Species of the genus Santinezia frequently present conspicuous sexual dimorphism.

Females of $S$. curvipes have differences with the males, on the yellow spots, showing additional spots on the groove III in the dorsal scute (Image 5). This species can be distinguished from $S$. albilineata, by the absence of spots inside mesotergal area III ( $S$. albilineata has two elongate spots) (Image 10).

Complete descriptions of this species were done by Roewer (1916) and González-Sponga (2003). Here we present only diagnostic characters.

Remarks: After studying specimens from two localities in the central track of Cordillera de la Costa, we do not find characters to separate the populations in as many species as it has been proposed in the literature (González-Sponga 2003). An analysis of the penis and morphometry suggests that the decision taken by Pinto-da-Rocha \& Kury (2003) was correct, proposing $S$. marcuzzi as a junior synonym of $S$. curvipes. The specimens of Parque Nacional El Ávila, were smaller than those of Parque Nacional Henri Pittier, and subtle differences have been observed in the position of the more distal mesal seta and the shape of the distal portion of the ventral plate (Figs. 4-6) however, they do not have other differences that allow us to separate them as two species.

An attempt to define the taxonomic status of Goniosoma marcuzzi was made, but the holotype of this species is lost (Rubén Candia pers. com., Dec 2009). We followed the decision of Pinto-da-Rocha $\&$ Kury (2003).

\section{Santinezia albilineata Roewer, 1923 (Revalidated) Images 6-10; Figs. 7-9.}

Santinezia albilineata Roewer, 1932: 290, fig 7; Soares \& Soares 1948: 617; Goodnight \& Goodnight, 1949: 23; Caporiacco, 1951: 27; Rambla, 1978: 8; Avram, 1987: 87; Decu et al., 1987: 34; Rambla \& Juberthie, 1994: 221 (type ZMB 7468, female holotype, not examined).

Santinezia curvipes: Pinto-da-Rocha \& Kury, 2003: 198.

Santinezia decui (Avram, 1987): 86, figs 16-19 (Types ISER female holotype lost?). (Synonymy established by González-Sponga 2003).

Material examined: 18.iv.2004, 11 males and 7 females, 1200m, road Tiara-La Esperanza, Aragua, Venezuela (MHNLS IV-244) (O. Villarreal M. \& H. Escalona); 19.x.1973 / 03.ix.1980, 12 males, 17 females, Campamento Rangel, Tiara, Aragua, (MAGS 016) (Ayala-Kaletta/A.R.D.G; V.A.G.D.; M.A.G.S.).

Emended diagnosis: Carapace uniform dark brown; mesotergum reticulated dark brown (Image 6). 


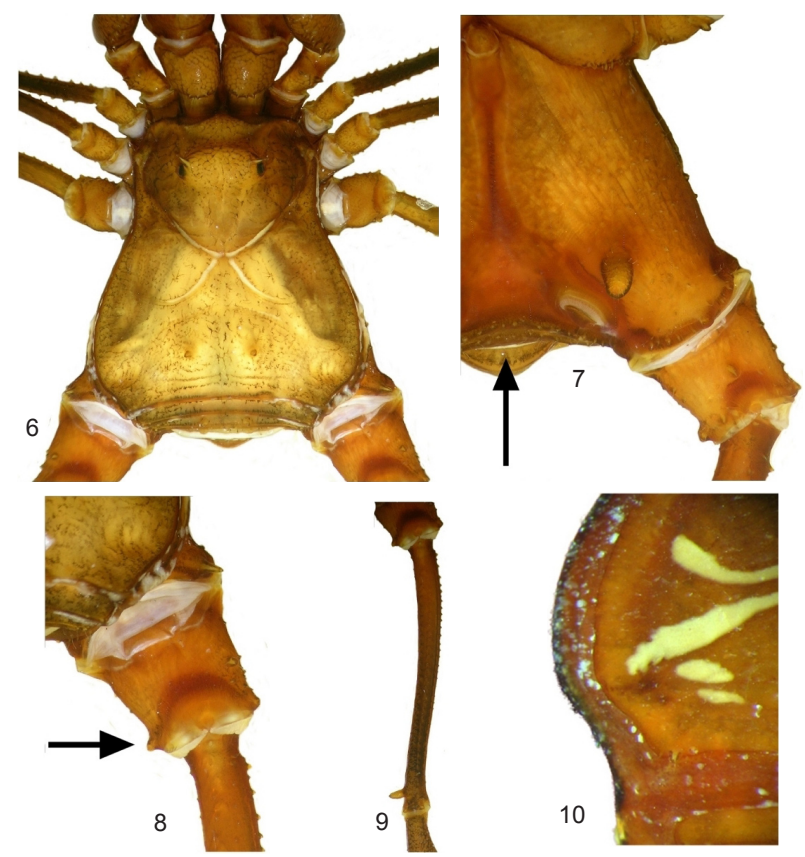

Images 6-10. Santinezia albilineata (male from Tiara, Aragua): 6 - Habitus in dorsal view; 7 - Coxa IV, stigmatic area and free sternites in ventral view; the arrow pointing the yellow strip on the sternite; 8 - Right trochanter IV in dorsal view; the arrow pointing the retrolateral tubercle on the trochanter; 9 - Right femur IV, in dorsal view; 10 - Female from Tiara, Aragua. Left posterolateral zone of dorsal scute, in dorsal view.

Santinezia albilineata can be differentiated easily from S. curvipes, by the following characters of the males: development and direction of the ventral process of the coxa IV, typical for the genus: in S. albilineata can be large (more than three times larger than wide) and perpendicular to direction of the coxa (Image 7), while in S. curvipes they are smaller and they are posteriorly projected, forming a acute angle with the posterior part of the coxa; form and direction of the retrolateral distal tubercle of the trochanter IV, perpendicular with blunt tip in S. albilineata (Image 8) and sharp and posteriorly projected in S. curvipes; retrolateral proximal tubercle of the femur IV absent (Images 8-9), this is present in S. curvipes. Penis: Ventral plate with 5 lateral setae, the 3 proximal aligned and larger. Distal setae distal straight. With 2 small mesodorsal setae. Apical portion of the truncus swollen, without dorsal projection. Ventral plate enlarged, with large/ width ratio: 1.48. Distal margin of the plate with a slight cleft (Figs. 7-9).

Females with two elongate spots on the mesotergal area III (Image 10).

Remarks: Santinezia albilineata Roewer,
1923 was described with material coming from San Casimiro, a locality in the south of Aragua State, in the central track of Cordillera de la Costa, Venezuela and posteriorly recorded from Rancho Grande, Aragua State and Los Teques, Miranda State (di Caporiacco 1951). González-Sponga (2003) in his taxonomic review of the genus in Venezuela redescribed this species with specimens from Tiara, a town near from the type-locality [the same presented by the Avram (1987) as a type-locality of $S$. decui, the latter species proposed as synonym of $S$. albilineata by GonzálezSponga (2003)].

In his phylogenetic analysis of Santinezia, Pintoda-Rocha \& Kury (2003) agreed with GonzálezSponga (2003) about the status of $S$. decui living in San Casimiro and around, however, both species are considered by them as junior synonyms of $S$. curvipes. These authors did not have access to material type of $S$. albilineata, mentioning that a request of this type material made to ISER (Dr. V. Decu) was not answered and that the material type could have been lost (Pintoda-Rocha \& Kury 2003).

Based on the study of some exemplars from Tiara, we propose the revalidation of Santinezia albilineata, keeping $S$. decui as its synonym. This species belongs to the group "curvipes" proposed by Pinto-da-Rocha $\&$ Kury (2003).

A detailed review of the species from Cordillera de la Costa in Venezuela is still needed to determine their taxonomic status. The taxonomic and geographical boundaries between species of Santinezia in this region are unknown.

\section{REFERENCES}

Avram, S. (1987). Opilionides du Venezuela IV. Fauna Hipogea y hemiedáfica de Venezuela y de otros países de América del Sur 1(8): 81-88.

di Caporiacco, L. (1951). Studi sugli aracnidi del Venezuela racolti dalla sezione di Biologia (Universitá Centrale del Venezuela). I parte: Scorpiones, Solifuga, Opiliones e Chernetes. Acta Biologica Venezuelica 1(1): 1-46.

González-Sponga, M.A. (2003). Arácnidos de Venezuela. Opiliones del género Santinezia (Laniatores, Cranaidae). Acta Biologica Venezuelica 21(4): 1-69.

Kury, A.B. (2003). Annotated catalogue of the Laniatores of the New World (Arachnida, Opiliones). Revista Iberica de Aracnología, vol. especial monográfico 1: 1-337.

Orrico, V.G.D. \& A.B. Kury (2009). A cladistic analysis of 
the Stygnicranainae Roewer, 1913 (Arachnida, Opiliones, Cranaidae) - where do longipalp cranaids belong? Zoological Journal of the Linnean Society 57: 470-494.

Pinto-da-Rocha, R. \& A. Kury (2003). Phylogenetic analysis of Santinezia with description of five new species (Opiliones, Laniatores, Cranaidae). Journal of Arachnology 31: 173-208.

Roewer, C.F. (1916). 7 neue Opilioniden des Zoolog. Museums in Berlin. Archiv für Naturgeschichte 81(12): 6-13.

Towndsend, V.R. \& M.A. Milne (2010). A new species of Santinezia (Opiliones: Cranaidae) from Panama. Journal of Arachnology 38: 460-465. 